\title{
What Is the Role of Work-Related Factors in Self-Reported Health Inequalities among Employed Individuals? A Longitudinal Study in Luxembourg
}

\author{
Anastase Tchicaya*, Nathalie Lorentz, Kristell Leduc \\ Living Conditions Department, Luxembourg Institute of Socio-Economic Research (LISER), \\ Esch-sur-Alzette, Luxembourg \\ Email: *anastase.tchicaya@liser.lu
}

How to cite this paper: Tchicaya, A., Lorentz, N. and Leduc, K. (2018) What Is the Role of Work-Related Factors in Self-Reported Health Inequalities among Employed Individuals? A Longitudinal Study in Luxembourg. Health, 10, 1141-1158.

https://doi.org/10.4236/health.2018.109087

Received: June 22, 2018

Accepted: September 2, 2018

Published: September 5, 2018

Copyright $\odot 2018$ by authors and Scientific Research Publishing Inc. This work is licensed under the Creative Commons Attribution International License (CC BY 4.0).

http://creativecommons.org/licenses/by/4.0/

(c) (i) Open Access

\begin{abstract}
Objectives: We measured health inequalities among employed Luxembourg residents over time and the socio-economic and work-related determinants. Design and Setting: Longitudinal data were obtained from the Socio-economic Liewen zu Lëtzebuerg/European Union Survey on Income and Living Conditions, which has been conducted each year since 2003 in Luxembourg. Participants: Participants comprised 727 Luxembourg residents ( $58 \%$ men), aged between 21 and 55 years in 2003, who were employed between 2003 and 2012. Primary and Secondary Outcomes Measured: The variable of interest was self-reported health. We used transition indicators on work-related factors to consider changes that individuals may have experienced in their job over this period. Results: People who moved from a part-time to a full-time contract (odds ratio (OR): 5.52, confidence interval (CI): 1.55 - 19.73), and those who moved from the $3 \mathrm{rd}$ or 4 th quartile of earnings to the 1st or 2nd quartile (OR: 2.48, CI: $1.02-6.05$ ) between 2003 and 2012, had a higher risk of being in poor health in 2012. The risk of deterioration in self-reported health in 2012 among people who were healthy in 2003 was associated with the type of contract, economic activity, and occupation. Conclusion: Health inequalities occur among employed people in Luxembourg. Their importance varies according to work-related characteristics and economic activity. Our findings showed that declined health status was associated with contract type, profession, and economic activity. This suggests that measures should be taken to maintain good health for people working in these specific occupations or economic sectors (e.g. preventive action, reduction of risk exposure, change of occupation in the same company, and so on).
\end{abstract}




\section{Keywords}

Employment, Health Inequalities, Working Conditions, EU-SILC, Work-Related Factors, Self-Reported Health

\section{Introduction}

Many studies have shown links between health and employment [1] [2] [3] [4] [5]. The work-related factors that can lead to health inequalities are multidimensional including income inequalities [6] [7]; different contract types [8]; the heterogeneity of the working conditions, specifically physical and mental difficulty; and the various types of career paths [9] [10] [11] [12]. However, the causal relationship between health and employment is often debated [13]. Indeed, difficult working conditions or a stressful environment can lead to a deterioration of self-reported health [14]. Meanwhile, self-reported health itself is likely to cause career interruption or an early exit from the labour market [4] [15].

In the European Union (EU), the percentage of employees with fixed-term contracts or other temporary contracts was lower and stable between 2003 and 2015, respectively $13 \%$ and $14 \%$ [16]. However, these national averages hide disparities with respect to certain characteristics related to the individual and his or her career, such as education level, economic activity, or occupation. For instance, the employment rate is lower for those who are less qualified (44\% in 2015) compared with those who are more qualified (83\% in 2015) [17] where sectorial heterogeneity exists in the duration of contracts. Research has already shown that disparities in working conditions could lead to adverse health effects and to health inequalities. This has been demonstrated in the Netherlands, where poor self-reported health is associated with hazardous physical working conditions [18]. Across the initial EU's 15-member states, Benavides also showed positive correlations between precarious employment and fatigue, backache, and muscular pain [19].

Specifically, in Luxembourg, with $10 \%$ of employees in temporary employment in 2015 [16] Luxembourg is one of the EU28 countries with a lower share of employees with fixed-term contracts or other temporary contracts. Therefore, this study addressed the relationship between health and employment by highlighting the role of socio-economic factors and work-related factors on health [20] [21] [22] [23]. The aim of this study was to measure the health inequalities among employed individuals over time and the socio-economic and work-related determinants among Luxembourg residents from 2003 to 2012.

\section{Materials and Methods}

\subsection{Data}

Data were derived from the Socio-economic Liewen zu Lëtzebuerg/European Union Survey on Income and Living Conditions (PSELL-3/EU-SILC), which has 
been conducted each year since 2003. However, since 2009, EUROSTAT (The Statistical Office of the European Communities) requires that one-quarter of the sample is renewed. This face-to-face survey focuses on a sample of households (5750 households, representing approximately 10,000 people) who live in Luxembourg and who have an affiliation with the Luxembourg social security system. All interviewers were able to speak the three official languages of Luxembourg (Luxembourgish, French and German). On average, an interview takes place for one hour; but it depends mostly on the number of people in the household. This survey has the advantage of providing both cross-sectional and longitudinal data. The cross-sectional data pool of the EU-SILC allows researchers to track changes in the income and living conditions of households for use in social protection policies [24]. The National Commission for Data Protection in Luxembourg approved the survey design and questionnaires.

In this study, the longitudinal sample included people aged 21 - 55 years who were present and employed in both 2003 and 2012. Therefore, 727 Luxembourg residents (58\% men) were analysed.

\subsection{Measures}

The self-reported health was considered as a dependent variable in this study. The variable regarding the self-reported health of individuals at the time of the survey was derived from the question: "How do you qualify your overall health?" The answer has five components: very good, good, fair, bad, and very bad. Health status was poor when a person declares fair, bad, or very bad health, and is considered as good when the individual reports to be in good or very good health. Self-reported health is subjective information, which can be affected by the past health of an individual, his actual health (outside of the framework of employment) or other sociocultural factors. However, this indicator is widely used in many studies [12] [18] [25]. It is usually considered in the literature as a reliable indicator in a population's health evaluation studies [26]. Self-reported health was considered as a robust predictor of life mortality [27].

The presence of any chronic (long-standing) illness and of any limitation in activities because of health problems are other parameters that can influence the overall perception of individuals of their self-reported health and this can reflect an overall health status running for several years. These health variables were assessed respectively by follow-up questions: "Do you suffer from/have any chronic (long-standing) illness or condition (health problem)?" and "For at least the last 6 months, have you been limited in activities people usually do because of a health problem?" (If limited, specify whether strongly limited or limited). Demographic variables examined included sex, age, nationality (Luxembourgish, Portuguese, and others), and marital status (never married, married, and separated/divorced/widower).

The socio-economic and work-related variables comprised the following:

1) Education level (primary, secondary, and tertiary).

2) Occupation (level 1: legislators, senior officials, managers, and profession- 
als; level 2: technicians and associate professionals, and armed forces; level 3: clerks, service workers, and shop and market sales workers; level 4: skilled agricultural workers, craft, and skilled workers; and level 5: elementary occupation) [28].

3) Contract type (permanent or fixed-term): derived from the question "Please, could you tell me what is the type of M.'s contract?"

4) Working-time (full-time or part-time): derived from the question "Does M. have a part-time or a full-time job?"

5) Economic activity (manufacturing, construction, wholesale, hotels, restaurants, transport, financial intermediation, real estate, lettings, public administration, education, health and social work, and others): derived from the question "Please describe the main activity of the local unit of the business or organisation where M. works?"

6) Gross wage distribution by quartile (in 2003: <€11.7/hour, €11.7 - €17.2, $€ 17.2$ - €23.0, and $\geq € 23.0$; in 2012: $<€ 16.7 /$ hour, $€ 16.7$ - €24.1, €24.1 - €34.5, and $\geq € 34.5)$.

Transition indicators on worked-related factors

Transition indicators on work-related factors were created to consider the changes that individuals may have experienced in their job from 2003-2012 and to assess the consequences of these changes in self-reported health [25]. They concerned professional advancement through a change in occupation, the evolution of contract type and the duration of the occupation, wage changes, and the continuity and stability of the career path by considering the frequency of employment changes and the number of unemployment periods (see Appendix).

Changes in self-reported health

It is considered positive when the individual declared a very bad, bad, or fair health status in 2003 and a good or very good health status in 2012 and vice versa. If the individual declared the same answer in 2003 and 2012, it means that there was no change in their self-reported health.

Change in contract type

It is considered as positive if there is a transition from a fixed-term contract to an open-ended contract $(-/+)$, as negative if the individual loses/quits his/her open-ended contract and gets a fixed-term contract $(+/-)$, and as stable when the contract does not change (stable and positive if the individual keeps his/her open-ended contract $(+/+)$, and stable and negative if the individual keeps his/her fixed-term contract (-I-).

Change in working-time

It is positive when the individual had a full-time contract in 2012 when he/she had a part-time contract in $2003(-/+)$ and vice versa. If the working-time remained stable between 2003 and 2012, there was no change: we distinguished stability with a full-time job $(+/+)$ from stability with a part-time job (-/-).

\subsection{Statistical Analysis}

In the first step, we analysed the relationship between the trajectory of self-reported 
health status and the individual characteristics and worked-related factors. The p-values were calculated by using the Chi-square test (threshold $\mathrm{p}$-value $<5 \%)$.

In the second step, two logistic regression models groups were used to assess the influence of education and work-related factors on the inequality in self-reported health. The first measured the association between self-reported health in 2012 and the evolution of employment characteristics (transition indicators) adjusted for demographics (sex, age, nationality, and marital status), socioeconomic (education level), and health (chronic conditions and activity limitation) characteristics in 2012. The second measured the probability of self-reported deterioration in 2012 amongst people who considered themselves in good or very good health in 2003, depending on the characteristics of employment in 2003 and was controlled for by using the demographic characteristics from 2003. For each logistic regression model group, we have calculated the univariable (Model 1) and multivariable (Model 2) odds-ratios to measure both the crude and adjusted values of associations. The univariable odds-ratio of the model 1 assess the probability of being in poor health by using only one independent variable (or covariate), while the multivariable odds-ratio in the model 2 includes all covariates. The results are significant to the error threshold of $5 \%$. Furthermore, due to the small sample, the generalised estimation equation (GEE) models were not used. All statistical analyses were performed using SAS 9.4 software (SAS Institute Inc., USA).

\section{Results}

Descriptive analyses showed links between education level, change in economic activity, occupation, type of contract, working time, and change in earnings on the one hand, and an individual's self-reported health and its evolution over time on the other (Table 1). Workers with a primary-level education were more likely to be in fair or poor health (31.7\%) compared to workers with a secondary- (19.2\%) or tertiary-level of education (12.4\%). These workers were also more likely to have experienced a deterioration of self-reported health between 2003 and 2012. Regarding occupation, employees who kept the same unskilled occupation (stable negative $(-l-)$ ) declared more frequently that they were in fair or poor health. Meanwhile, those who experienced occupational transitions upward between 2003 and 2012 (positive $(-/+)$ ) more often reported positive changes in their health (18\%). Moreover, workers whose quartile of earnings decreased during the period were those who declared themselves more often to be in fair or poor health (31.9\%).

In Table 2, logistic regression modelling showed that being in poor health was associated with a change in work-related factors, particularly in the univariable (or unadjusted) models. The probability of being in poor health was the highest among people who stayed in a job of a lower level, a non-permanent contract, moved from part-time to full-time, or changed of wage quartile. These results 
were confirmed in model 2 only for working-time and evolution of wage quartile. Indeed, people who moved from a part-time contract in 2003 to a full-time contract in 2012 had a higher risk of being in poor health in 2012 (odds ratio $(O R)=5.41,95 \%$ confidence interval: $(C I): 1.52-19.23)$. The odds of being in poor health in 2012 were higher for individuals who moved from the $3 \mathrm{rd}$ or 4 th quartile of earnings in 2003 to the 1st or 2nd quartile of earnings in 2012 (OR = 2.46, 95\% CI: 1.01 - 6.03). No significant associations were found between self-reported health in 2012 and a change in contract type (open-ended contracts or other types of contracts), having experienced at least one period of unemployment, and the frequency of job changes between 2003 and 2012.

In Table 3, the risk of deterioration of self-reported health in 2012 among people who were healthy in 2003 was associated with contract type, economic activity, and occupation, in both in models 1 and 2. Indeed, the odds of being in poor health in 2012 among people who were healthy in 2003 were higher for individuals who worked in construction in 2003 compared to those in administration, education, or health ( $\mathrm{OR}=5.15,95 \% \mathrm{CI}: 1.53$ - 17.31). Technicians, associate professionals, and armed forces $(\mathrm{OR}=2.63,95 \% \mathrm{CI}$ : $1.03-6.71)$; clerical support workers, service, and sales workers ( $\mathrm{OR}=3.15,95 \% \mathrm{CI}: 1.10-9.01)$; and workers in elementary occupations (OR $=5.92,95 \% \mathrm{CI}: 1.57-22.28)$ had a higher risk of poor health compared to managers and professionals. Finally, people with a non-permanent contract in 2003 had a higher chance of poor health in 2012 compared to those with a permanent contract ( $\mathrm{OR}=2.74,95 \%$ CI: 1.15 - 6.57).

Table 1. Relationship between the trajectory of the self-reported health status and the individual characteristics and work-related factors among people aged 30 - 64 in 2012 and in employment in 2012 and 2003 ( $\mathrm{N}=727)$.

\begin{tabular}{|c|c|c|c|c|c|c|c|}
\hline & \multirow[b]{2}{*}{$\mathbf{N}$} & \multicolumn{2}{|c|}{$\begin{array}{l}\text { Poor self-reported health in } \\
2012\end{array}$} & \multicolumn{4}{|c|}{$\begin{array}{c}\text { Trajectory of self-reported health status } \\
\text { between } 2003 \text { and } 2012\end{array}$} \\
\hline & & $\%$ & $\mathrm{p}$-value ${ }^{*}$ & $\begin{array}{c}\text { Positive } \\
\text { evolution (\%) }\end{array}$ & $\begin{array}{c}\text { No } \\
\text { evolution (\%) }\end{array}$ & $\begin{array}{c}\text { Negative } \\
\text { evolution (\%) }\end{array}$ & p-value ${ }^{*}$ \\
\hline Total & 727 & 19.8 & & 6.7 & 80.3 & 13.0 & \\
\hline Male & 424 & 20.1 & 0.8014 & 6.7 & 78.7 & 14.6 & 0.3230 \\
\hline Female & 303 & 19.4 & & 6.8 & 82.5 & 10.8 & \\
\hline \multicolumn{8}{|l|}{ Age (years) } \\
\hline$[30-40]$ & 211 & 13.9 & 0.0084 & 3.8 & 87.6 & 8.6 & 0.0222 \\
\hline$[50-64]$ & 215 & 25.8 & & 6.9 & 76.8 & 16.3 & \\
\hline \multicolumn{8}{|l|}{ Nationality } \\
\hline Luxembourgish & 423 & 16.1 & 0.0001 & 5.0 & 84.7 & 10.3 & 0.0054 \\
\hline Portuguese & 139 & 32.5 & & 9.4 & 71.0 & 19.6 & \\
\hline Other & 165 & 18.6 & & 9.0 & 76.7 & 14.4 & \\
\hline
\end{tabular}




\begin{tabular}{|c|c|c|c|c|c|c|c|}
\hline \multicolumn{8}{|l|}{ Marital status } \\
\hline Never married & 139 & 21.5 & 0.5770 & 9.1 & 81.8 & 9.1 & 0.3242 \\
\hline Married & 514 & 18.8 & & 6.6 & 79.6 & 13.7 & \\
\hline Separated/divorced/widowed & 74 & 23.2 & & 3.2 & 81.8 & 15.0 & \\
\hline \multicolumn{8}{|l|}{ Education level } \\
\hline Primary & 154 & 31.7 & $<0.0001$ & 6.6 & 74.5 & 19.0 & 0.0226 \\
\hline Secondary & 356 & 19.2 & & 7.7 & 79.4 & 12.9 & \\
\hline Tertiary & 214 & 12.4 & & 4.2 & 86.9 & 8.9 & \\
\hline \multicolumn{8}{|l|}{ Economic activity } \\
\hline Manufacturing & 87 & 21.7 & 0.2778 & 10.9 & 77.1 & 12.0 & 0.0065 \\
\hline Construction & 54 & 28.9 & & 14.9 & 61.7 & 23.4 & \\
\hline Wholesale, hotels, restaurants, transport & 146 & 13.9 & & 5.7 & 85.8 & 8.5 & \\
\hline Financial intermediation, real estate, lettings & 78 & 20.1 & & 1.9 & 80.0 & 18.1 & \\
\hline $\begin{array}{l}\text { Public administration, education, health and } \\
\text { social work }\end{array}$ & 294 & 20.4 & & 5.1 & 82.9 & 12.0 & \\
\hline Others & 68 & 19.7 & & 9.7 & 76.5 & 13.9 & \\
\hline \multicolumn{8}{|l|}{ Economic activity change } \\
\hline Yes & 178 & 15.0 & 0.0631 & 10.4 & 81.7 & 7.9 & 0.0096 \\
\hline No & 549 & 21.4 & & 5.6 & 79.8 & 14.6 & \\
\hline \multicolumn{8}{|l|}{ Occupation } \\
\hline Stable positive $(+/+)$ & 249 & 14.0 & 0.0016 & 4.4 & 84.9 & 10.7 & 0.0015 \\
\hline Stable negative $(-/-)$ & 301 & 25.9 & & 8.2 & 77.5 & 14.3 & \\
\hline Negative (+/-) & 119 & 20.8 & & 2.6 & 81.2 & 16.3 & \\
\hline Positive $(-/+)$ & 58 & 11.0 & & 18.0 & 72.9 & 9.2 & \\
\hline \multicolumn{8}{|l|}{$\begin{array}{c}\text { Employment contract } \\
\text { (permanent contract/others) }\end{array}$} \\
\hline Stable positive $(+/+)$ & 636 & 18.0 & 0.0044 & 6.2 & 81.1 & 12.7 & 0.1718 \\
\hline Stable negative $(-/-)$ & 10 & 54.6 & & 6.4 & 93.6 & 0.0 & \\
\hline Negative $(+/-)$ & 16 & 31.2 & & 5.7 & 79.9 & 14.4 & \\
\hline Positive $(-/+)$ & 56 & 28.6 & & 14.5 & 67.7 & 17.8 & \\
\hline \multicolumn{8}{|l|}{ Working-time (Part-time/Full time) } \\
\hline Stable positive $(+/+)$ & 548 & 18.2 & 0.0854 & 6.8 & 80.7 & 12.5 & 0.0545 \\
\hline Stable negative $(-/-)$ & 99 & 23.1 & & 11.0 & 72.3 & 16.7 & \\
\hline Negative (+/-) & 57 & 22.8 & & 0.8 & 83.1 & 16.0 & \\
\hline Positive $(-/+)$ & 21 & 38.7 & & 0.3 & 98.1 & 1.6 & \\
\hline \multicolumn{8}{|l|}{$\begin{array}{l}\text { Unemployment period } \\
\text { between } 2003 \text { and } 2012\end{array}$} \\
\hline At least one & 78 & 15.9 & 0.3547 & 14.6 & 73.6 & 11.9 & 0.0137 \\
\hline
\end{tabular}




\section{Continued}

None

649

20.3

Frequency of job changes

between 2003 and 2012

$\begin{array}{cccccccc}\text { None } & 494 & 21.2 & 0.3890 & 4.0 & 82.6 & 13.3 & 0.0011 \\ \text { One } & 151 & 16.4 & & 12.8 & 74.0 & 13.2 & \\ 2 \text { or more } & 82 & 17.8 & & 11.9 & 77.6 & 10.4\end{array}$

Evolution of wage quartile

\begin{tabular}{|c|c|c|c|c|c|c|c|}
\hline Stable positive $(+/+)$ & 306 & 16.1 & 0.0515 & 6.0 & 81.9 & 12.2 & 0.2128 \\
\hline Stable negative $(-/-)$ & 309 & 21.4 & & 9.2 & 77.1 & 13.8 & \\
\hline Negative (+/-) & 49 & 31.9 & & 2.6 & 87.1 & 10.2 & \\
\hline Positive $(-/+)$ & 61 & 21.4 & & 1.6 & 82.6 & 15.9 & \\
\hline
\end{tabular}

Source: PSELL-EU-SILC 2003-2012; authors' calculations. *: p-values were calculated using Chi-square test.

Table 2. Modelling for the probability of being in fair or poor health in 2012 according to a change in individual characteristics and to work-related factors $(\mathrm{N}=727)$.

\begin{tabular}{|c|c|c|c|c|}
\hline & Model 1 & & Model 2 & \\
\hline & ORu & $95 \% \mathrm{CI}$ & OR adjusted & $95 \%$ CI \\
\hline \multicolumn{5}{|l|}{ Gender } \\
\hline Female & ref. & & ref. & \\
\hline Male & 1.05 & {$[0.72-1.52]$} & $2.50^{* *}$ & {$[1.31-4.79]$} \\
\hline \multicolumn{5}{|l|}{ Age } \\
\hline [30 - 39] & ref. & & ref. & \\
\hline$[40-49]$ & 1.52 & {$[0.94-2.47]$} & 1.41 & {$[0.76-2.61]$} \\
\hline$[50-64]$ & $2.16^{* *}$ & {$[1.32-3.55]$} & $2.83^{\star}$ & {$[1.47-5.43]$} \\
\hline \multicolumn{5}{|l|}{ Nationality } \\
\hline Luxembourgish & ref. & & ref. & \\
\hline Portuguese & $2.51^{* * *}$ & {$[1.62-3.90]$} & $6.11^{* * *}$ & [2.63 - 14.19] \\
\hline Other & 1.19 & {$[0.74-1.90]$} & $2.74^{* *}$ & {$[1.40-5.36]$} \\
\hline \multicolumn{5}{|l|}{ Marital Status } \\
\hline Married & ref. & & ref. & \\
\hline Never married & 1.18 & {$[0.74-1.87]$} & 1.64 & {$[0.88-3.04]$} \\
\hline Separated/divorced/widowed & 1.30 & {$[0.73-2.33]$} & 1.47 & {$[0.70-3.11]$} \\
\hline \multicolumn{5}{|l|}{ Chronic disease } \\
\hline No & ref. & & ref. & \\
\hline Yes & $6.06^{* * *}$ & {$[3.97-9.25]$} & $4.87^{* * *}$ & {$[2.90-8.18]$} \\
\hline
\end{tabular}




\section{Continued}

Activity limitations

No

Yes

\section{Level of education}

Tertiary

Primary

Secondary

\section{Occupation}

Stable positive $(+/+)$

Stable negative (-/-)

Negative (+/-)

Positive $(-/+)$

Employment contract (permanent contract/others)

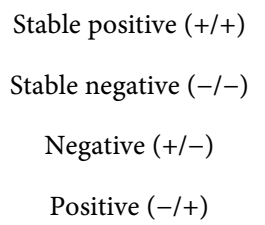

Working-time (Part-time/Full-time)

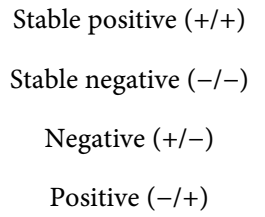

Unemployment period between 2003 and 2012

\author{
None \\ At least one
}

Frequency of job changes between 2003 and 2012

None
One

Two or more

\section{Evolution of wage quartile}

$$
\begin{gathered}
\text { Stable positive }(+/+) \\
\text { Stable negative }(-/-) \\
\text { Negative }(+/-) \\
\text { Positive }(-/+)
\end{gathered}
$$

$\mathrm{R}^{2}$ ref.

$6.44^{* * *}$

[4.09 - 10.13]

ref.

$5.92^{* * *}$

$[3.39-10.34]$

ref.

2.51

$[0.88-7.12]$

$2.62^{*}$

$[1.23-5.62]$

[1.03 - 2.71]

ref.

$2.15^{\star * *}$

[1.39 - 3.35]

[0.91-2.85]

$[0.31-1.87]$

0.76

ref.

$5.49^{\star *}$

[1.56 - 19.39]

[0.71 - 6.07]

[0.99 - 3.38]

1.83

ref.

1.35

[0.81 - 2.25]

[0.69 - 2.56]

[1.15 - 6.99]

$2.84^{*}$

ref.

0.74

[0.39 - 1.40]

ref.

0.82

[0.32 - 2.07]

ref.

0.73

0.81

ref.

1.43

$2.45^{* *}$

1.42
[0.45 - 1.18]

[0.44 - 1.48] ref.

1.35

1.42

0.69

ref.

3.23

2.08

1.56

ref.

2.20

2.16

[0.95 - 5.09]

[0.79 - 5.93]

[1.52 - 19.23]

$5.41^{* *}$

[0.22 - 2.20]

$$
\begin{gathered}
{[0.66-15.83]} \\
{[0.50-8.59]} \\
{[0.68-3.59]}
\end{gathered}
$$

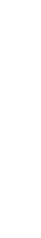


Table 3. Modelling for the probability of being in fair or poor health in 2012 among persons in good health in 2003 according to the individual characteristics and the work-related factors of $2003(\mathrm{~N}=628)$.

\begin{tabular}{|c|c|c|c|c|}
\hline & Model 1 & & Model 2 & \\
\hline & ORu & $95 \% \mathrm{CI}$ & OR adjusted & $95 \% \mathrm{CI}$ \\
\hline \multicolumn{5}{|l|}{ Gender } \\
\hline Female & ref. & & ref. & \\
\hline Male & 1.36 & {$[0.86-2.16]$} & 1.45 & {$[0.74-2.84]$} \\
\hline \multicolumn{5}{|l|}{ Age (years) } \\
\hline [21 - 29] & ref. & & ref. & \\
\hline [30 - 39] & 1.51 & {$[0.82-2.80]$} & 1.59 & {$[0.75-3.37]$} \\
\hline$[40-49]$ & $2.12^{*}$ & {$[1.13-3.98]$} & $2.57^{\star}$ & {$[1.17-5.64]$} \\
\hline$[50-64]$ & 2.51 & {$[0.91-6.92]$} & 3.40 & {$[0.99-11.68]$} \\
\hline \multicolumn{5}{|l|}{ Nationality } \\
\hline Luxembourgish & ref. & & ref. & \\
\hline Portuguese & $1.89^{*}$ & {$[1.11-3.21]$} & 1.85 & {$[0.77-4.45]$} \\
\hline Other & 1.10 & {$[0.64-1.88]$} & 1.27 & {$[0.64-2.54]$} \\
\hline \multicolumn{5}{|l|}{ Marital status } \\
\hline Married & ref. & & ref. & \\
\hline Never married & 0.64 & {$[0.38-1.09]$} & 0.91 & {$[0.45-1.83]$} \\
\hline Separated/divorced/widowed & 1.23 & {$[0.60-2.53]$} & 1.43 & {$[0.61-3.32]$} \\
\hline \multicolumn{5}{|l|}{ Chronic disease } \\
\hline No & ref. & & ref. & \\
\hline Yes & 1.47 & {$[0.77-2.80]$} & 1.37 & {$[0.66-2.86]$} \\
\hline \multicolumn{5}{|l|}{ Activity limitations } \\
\hline No & ref. & & ref. & \\
\hline Yes & $3.18^{* * *}$ & {$[1.74-5.83]$} & $2.37^{\star}$ & {$[1.17-4.79]$} \\
\hline \multicolumn{5}{|l|}{ Level of education } \\
\hline Tertiary & ref. & & ref. & \\
\hline Primary & $2.00^{*}$ & {$[1.07-3.73]$} & 0.57 & {$[0.19-1.69]$} \\
\hline Secondary & 1.64 & {$[0.93-2.91]$} & 1.10 & {$[0.50-2.46]$} \\
\hline \multicolumn{5}{|l|}{ Economic activity } \\
\hline $\begin{array}{l}\text { Public administration, education, } \\
\text { health and social work }\end{array}$ & ref. & & ref. & \\
\hline Manufacturing & 1.05 & {$[0.45-2.43]$} & 1.43 & {$[0.52$ - 3.97] } \\
\hline Construction & $3.08^{\star *}$ & {$[1.39-6.83]$} & $5.14^{* *}$ & {$[1.53-17.31]$} \\
\hline Wholesale, hotels, restaurants, transport & 0.87 & {$[0.44-1.71]$} & 1.15 & {$[0.49-2.70]$} \\
\hline Financial intermediation, real estate, lettings & 1.11 & {$[0.59-2.11]$} & 1.57 & {$[0.74-3.33]$} \\
\hline Others & 1.60 & {$[0.77-3.30]$} & 1.42 & {$[0.60-3.34]$} \\
\hline Occupation & & & & \\
\hline
\end{tabular}




\section{Continued}

Level 1: Legislators, senior official, managers,

$$
\text { and professionals }
$$

Level 2: Technicians and associate professionals, armed forces

Level 3: Clerks, service workers, shop and market sales

$$
\text { workers }
$$

Level 4: Skilled agricultural workers, craft, and skilled workers

Level 5: Elementary occupation

Employment contract (permanent contract/others)

Permanent contracts

Others

Working-time (Part-time/Full time)

Full-time

Part-time

Wage quartile

3 rd or 4 th quartile

1st quartile

2nd quartile

$\mathrm{R}^{2}$ ref.

2.03

1.92

$2.52^{*}$

$4.06^{* * *}$

ref.

1.65

ref.

1.27

ref.

1.24

1.32 ref.

$2.63^{*}$

[1.03 - 6.71]

$[1.10-9.01]$

[0.63 - 6.96]

$[1.57-22.28]$

[1.77 - 9.30]

$5.92^{\star *}$

ref.

$2.74^{*}$

$[1.15-6.57]$

ref.

1.33

[0.60 - 2.97]

[0.71 - 2.26]

ref.

[0.73 - 2.11]

0.73

[0.31 - 1.74]

$[0.77-2.25]$

1.14

[0.57 - 2.26]

0.0776

${ }^{*} \mathrm{p}<0.05,{ }^{* *} \mathrm{p}<0.01,{ }^{* *} \mathrm{p}<0.0001$. Model 1: a model with one independent variable; ORu: Univariable Odds Ratio (or unadjusted OR); Model 2: a model with all independent variables in the table; OR adjusted: Adjusted Odds Ratio (or multivariable OR). Source: PSELL-EU-SILC 2003-2012; authors' calculations.

\section{Discussion}

The results of this study showed health inequalities among the employed cohort between 2003 and 2012. These inequalities in self-reported health were associated with wage level, economic activity, occupation, type of contract, and evolution in the type of job.

Our findings showed that people who experienced a negative evolution of wage quartile between 2003 and 2012 perceived poor self-reported health. Previous studies have generally sought to identify the link between income inequalities and self-reported health rather than the link between the distribution of income within a population and self-reported health [6] [29]. Nevertheless, a 2004 study indicated that individuals with high salaries declared good or very good health more frequently compared to others [30].

No significant relationship was found between self-reported health in 2012 and the frequency of changes in employment between 2003 and 2012, which was consistent with other studies [12] [25]. On the other hand, our study found no association between self-reported health in 2012 and has experienced at least one period of unemployment between 2003 and 2012. In France, an association was found in 2010: people who have known at least one period of unemployment, regardless of the duration, more frequently perceived their health as fair or poor 
than those who did not [25].

About the deterioration of self-reported health between 2003 and 2012, our results showed that individuals who worked in 2003 in the construction sector had the greatest odds of declining health in 2012 compared to those working in the administration, education, or the health sector. Debrand and Lengagne also studied the link between difficult working conditions such as physically arduous work and self-reported health among older workers [10]. They noted that these workers declared that they were in poor health more frequently than older workers with no difficult working conditions.

The association between occupation and self-reported health shows that clerical support workers, service and sales workers, and workers in elementary occupations had a higher risk of perceiving their health as poor or very poor compared to managers and professionals. This result is consistent with Ortiz, who highlights that being workers or employees, as opposed to managers, regardless of their qualifications, increased the probability of poor self-reported health [12]. Moreover, the lowest-qualified workers work more frequently than other workers in the sectors that have harsher working conditions. In Brazil, Szwarcwald and colleagues noted that all other factors being equal, having a position that requires low skills (e.g. manual worker) and having an occupation with precarious working conditions were positively linked to poor self-reported health [31].

People who had moved from a part-time to a full-time job between 2003 and 2012 were more likely to report poor health than others were. This working-time effect is considered to have detrimental effects on the health and psychological being-well of workers [32]. Furthermore, when examining the employed people with good health in 2003, the risk of a deterioration of their self-reported health in 2012 was higher among those who did not have a permanent contract in 2003. In 2016, Kwon and colleagues found that non-permanent workers were 1.2 times more likely to declare poor health compared to permanent workers who were true even when socio-demographic factors, work environment, and work hazards were adjusted for [33]. Other studies have observed that temporary employment exerts an adverse effect on health, which could be explained by the structural insecurity related to contract and income instability and worse working conditions, compared to workers with open-ended contracts [34].

Kim combined these two work-related factors in one of his studies and showed that people with a precarious job (i.e. in temporary work or with part-time and or fixed-term contracts) declared more frequently than others to be in poor health [35]. In 2017, Bacci and colleagues found that employees with part-time, permanent work and those with full-time, temporary job had a significantly higher disadvantage in self-health status compared to full-time permanent workers [34]. In Japan, Tsurugano and colleagues also compared the self-reported health of two categories of Japanese workers: those with a precarious contract (e.g. part-time work, fixed-term) and those with a permanent contract (survey data based on 205,994 people in 2007) [36]. These authors have shown that precarious contracts were associated with fair or poor self-reported health and psychologi- 
cal distress and that these results have been particularly significant among people with full-time jobs. The impact of job contracts on health was not obvious among workers working fewer than 40 hours per week compared to full-time workers.

Moreover, Tsurugano and colleagues found links between precarious contracts and fair or poor self-reported health, subjective symptoms, and unhealthy behaviour [36]. Their results suggest that inequality in the workplace, such as having long working hours with a precarious contract, is detrimental to workers' health. As far as temporary work is concerned, Virtanen and colleagues conducted a literature review on the relationship between temporary employment and health [37]. They observed that there was higher psychological morbidity among temporary workers than among permanent workers. Nonetheless, even employees with a permanent contract can face insecurity in their job, which is likely to cause psychological problems or stress and leads to a deterioration in global health [38].

Limitations and strengths

Our study was based on a longitudinal sample combining ten waves from the EU-SILC. It was a significant advantage to be able to analyse the health changes of employed people. Nevertheless, we did not consider that some of the individuals had exited the labour market and did not return during this period. Consequently, this has greatly reduced the sample size. It has also prevented us from categorising some explanatory variables more accurately. The lack of some important variables related to employment, which may have a direct or indirect link with self-reported health such as autonomy in tasks or latitude in decision-making, stressful or arduous working conditions, or even the feeling of either job insecurity and instability or job satisfaction is also a study limitation [8] [9] [10] [39]. Nevertheless, we consider that these aspects could have been implicitly integrated by the other variables we used (e.g. type of contract, economic activity, and occupation).

Due to the small sample, it was not possible to conduct analyses by sex like Schrijvers [18], and Liukkonen [40] did. Indeed, women and men often have different career paths because women have more frequent career breaks or reductions in their working-time to reconcile their personal and professional life better and this too can be linked with their self-reported health.

Finally, this study presents a selection bias. Indeed, during the study period, some employees with more severe health problems were forced to leave the labour market. There is also a problem of endogeneity in the relationship between employment and health; however, this endogeneity problem is sometimes useful for control purposes, especially in the framework of career-path issues.

\section{Conclusion}

Health inequalities occur among employed people, and their importance depends on both work-related characteristics and the type of economic activi- 
ty/sector of the individual. Indeed, our findings showed that declined health status in 2012 in people with good health in 2003 was associated with the type of contract, profession, and economic activity. Therefore, measures should be taken to reduce exposure to occupational risks and arduous working conditions across varied economic activities and occupations. Specifically, it is necessary to implement management policies concerning, amongst others, improvement in working conditions, the prevention of difficult/hard working conditions, and other preventative actions to protect human health.

\section{Declarations}

\section{Acknowledgements}

We thank the editorial team and anonymous referees for helpful comments. So, the views expressed herein are of the authors.

\section{Authors' Contributions}

A.T and N.L. conducted the statistical analysis and wrote the manuscript. K.L. wrote the manuscript. All authors read and approved the final manuscript.

\section{Funding}

This study received no specific grant from any funding agency in public, commercial or not-for-profit sectors.

\section{Conflicts of Interest}

The authors declare no conflict of interest.

\section{Consent for Publication}

Not applicable.

\section{Ethics Approval and Consent to Participate}

All of the households that were selected for participation in the PSELL/EU-SILC survey received a pre-notification letter in which the survey topic and contents, interview, and voluntary nature of the study were described. Therefore, signed informed consent was not necessary. The National Commission approved the survey design and questionnaires for Data Protection of Luxembourg.

\section{Availability of Data and Materials}

Data used from the PSELL/EU-SILC survey (Panel Socio-Economique-Liewen $\mathrm{zu}$ Letzerbuerg/European Union-Survey on Income and Living Conditions) which is part of the Luxembourg Socio-economic panel, conducted by LISER and Statec, and part of the EU-SILC is managed by Eurostat. Currently, the authors cannot make data publicly available because they have not the right to do it. Data supporting the conclusions of this article are included in the article. 


\section{References}

[1] Lallukka, T., Sarlio-Lähteenkorva, S., Roos, E., Laaksonen, M., Rahkonen, O. and Lahelma, E. (2004) Working Conditions and Health Behaviours among Employed Women and Men: The Helsinki Health Study. Preventive Medicine, 38, 48-56. https://doi.org/10.1016/j.ypmed.2003.09.027

[2] Haan, P. and Myck, M. (2009) Dynamics of Health and Labor Market Risks. Journal of Health Economics, 28, 1116-1125. https://doi.org/10.1016/j.jhealeco.2009.09.001

[3] Ki, M., Sacker, A., Kelly, Y. and Nazroo, J. (2011) Health Selection Operating between Classes and across Employment Statuses. Journal of Epidemiology and Community Health, 65, 1132-1139. https://doi.org/10.1136/jech.2009.107995

[4] Zucchelli, E., Harris, M. and Zhao, X. (2012) Ill-Health and Transitions to Part-Time Work and Self-Employment among Older Workers. Centre for Research in Applied Economics Working Paper Series: No. 03032012.

https://doi.org/10.2139/ssrn.2378174

[5] Kerkhofs, M. and Lindeboom, M. (1997) Age Related Health Dynamics and Changes in labour Market Status. Health Economics, 6, 407-423.

https://doi.org/10.1002/(SICI)1099-1050(199707)6:4<407::AID-HEC275>3.0.CO;2$\underline{\mathrm{N}}$

[6] Kawachi, I. and Kennedy, B.P. (1999) Income Inequality and Health: Pathways and Mechanisms. Health Services Research, 34, 215-227.

[7] Subramanian, S.V. (2004) Income Inequality and Health: What Have We Learned So Far? Epidemiologic Reviews, 26, 78-91. https://doi.org/10.1093/epirev/mxh003

[8] Virtanen, P., Vahtera, J., Kivimäki, M., Liukkonen, V., Virtanen, M. and Ferrie, J. (2005) Labor Market Trajectories and Health: A Four-Year Follow-Up Study of Initially Fixed-Term Employees. American Journal of Epidemiology, 161, 840-846. https://doi.org/10.1093/aje/kwi107

[9] Bihr, A. and Pfefferkorn, R. (2008) Les inégalités sociales de santé. [Social Inequalities in Health.] La Découverte, Paris, 271.

[10] Debrand, T. and Lengagne, P. (2007) Pénibilité au travail et santé des seniors en Europe? [Stress at Work and the Health of Older Workers in Europe?] Economic Statistics, 403, 19-38. https://doi.org/10.3406/estat.2007.7086

[11] Virtanen, P., Vahtera, J., Broms, U., Sillanmäki, L., Kivimäki, M. and Koskenvuo, M. (2008) Employment Trajectory as Determinant of Change in Health-Related Lifestyle: The Prospective HeSSup Study. European Journal of Public Health, 18, 504-508. https://doi.org/10.1093/eurpub/ckn037

[12] Ortiz, A. (2009) Trajectoire professionnelle et état de santé déclaré des salariés seniors en activité. [Professional Career and Self-Reported Health of Older Workers.] Revue d'économie politique, 60, 365. https://doi.org/10.3917/reco.602.0365

[13] Barnay, T. (2005) Santé déclarée et cessation d'activité. [Self-Reported Health and Cessation of Activity.] Revue française d'économie, 20, 73-106. https://doi.org/10.3406/rfeco.2005.1573

[14] Volkoff, S. (2014) Perspectives interdisciplinaires sur le travail et la santé. [Interdisciplinary Perspectives on Work and Health.] Boulot, 1, 1-12.

[15] Jusot, F., Khlat, M., Rochereau, T. and Sermet, C. (2006) Une mauvaise santé augmente fortement les risques de perte d'emploi. [Bad Health Greatly Increases the Risk of Unemployment.] Données sociales: La société française, Paris, 533-542.

[16] EUROSTAT (2016) Temporary Employees as Percentage of the Total Number of 
Employees.

https://ec.europa.eu/eurostat/tgm/table.do?tab=table\&init=1\&language=en\&pcode $=$ tesem $110 \&$ plugin $=1$

[17] EUROSTAT (2016) Employment Rates by Educational Attainment Level. http://appsso.eurostat.ec.europa.eu/nui/show.do?dataset=lfsa_ergaed\&lang=en

[18] Schrijvers, C.T., van de Mheen, H.D., Stronks, K. and Mackenbach, J.P. (1998) Socioeconomic Inequalities in Health in the Working Population: The Contribution of Working Conditions. International Journal of Epidemiology, 27, 1011-1018. https://doi.org/10.1093/ije/27.6.1011

[19] Benavides, F.G., Benach, J., Diez-Roux, V. and Roman, C. (2000) How Do Types of Employment Relate to Health Indicators? Findings from the Second European Survey on Working Conditions. Journal of Epidemiology and Community Health, 54, 494-501. https://doi.org/10.1136/jech.54.7.494

[20] Benach, J., Gimeno, D., Benavides, F.G., Martínez, J.M., Del, M. and Torné, M.A.R. (2004) European Union Changes from 1995 to 2000. Public Health, 14, 314-321.

[21] Benach, J., Mcknight, A., Goldblatt, P., Duarte, M.V., Weitkowitz, H., Wester, G., Siegrist, J., Inequalities, H., Sciences, H., Fabra, P., Kingdom, U. and Muntaner, C. (2010) Employment Arrangements, Work Conditions and Health Inequalities. 1-86.

[22] Hammarström, A., Virtanen, P. and Janlert, U. (2011) Are the Health Consequences of Temporary Employment Worse among Low Educated than among High Educated? European Journal of Public Health, 21, 756-761. https://doi.org/10.1093/eurpub/ckq135

[23] Ravesteijn, B., Kippersluis, H.V. and Doorslaer, E.V. (2013) The Wear and Tear on Health: What Is the Role of Occupation? SOEP-German Socio-Economic Panel Study at DIW Berlin, Berlin, 618, 33 p.

[24] EUROSTAT (2016) European Union Statistics on Income and Living Conditions. http://epp.eurostat.ec.europa.eu/statistics_explained/index.php/Glossary:EU-SILC

[25] Coutrot, T., Rouxel, C., et al. (2010) Parcours professionnels et état de santé (Career paths and health status). Premières synthèses, Dares, 1-10.

[26] Debooser, et al. (2011) Santé perçue. Atlas la santé du Soc. Bruxelles-Capitale (Self-Rated Health. Health Atlas in Brussel). Obs. la santé du Soc. Bruxelles, 111-137.

[27] OECD (2011) Health at a Glance 2011: OECD Indicators. OECD Publishing, Paris. https://doi.org/10.1787/health_glance-2011-en

[28] International Labour Organization (ILO) International Standard Classification of Occupations. http://www.ilo.org/public/english/bureau/stat/isco/isco08/

[29] Kennedy, B.P., Kawachi, I., Glass, R. and Prothrow-Stith, D. (1998) Income Distribution, Socioeconomic Status, and Self-Rated Health in the United States: Multilevel Analysis. BMJ, 317, 917-921. https://doi.org/10.1136/bmj.317.7163.917

[30] Lopez, R. (2004) Income Inequality and Self-Rated Health in US Metropolitan Areas: A Multi-Level Analysis. Social Science \& Medicine, 59, 2409-2419. https://doi.org/10.1016/j.socscimed.2004.03.033

[31] Szwarcwald, C.L., et al. (2005) Socio-Demographic Determinants of Self-Rated Health in Brazil. World Health, 21, 54-64. https://doi.org/10.1590/S0102-311X2005000700007

[32] Angrave, D. and Charlwood, A. (2015) What Is the Relationship between Long Working Hours, Over-Employment, Under-Employment and the Subjective Well-Being of Workers? Longitudinal Evidence from the UK. Human Relations, 68 , 1491-1515. https://doi.org/10.1177/0018726714559752 
[33] Kwon, K., Park, J.B., Lee, K.-J. and Cho, Y.-S. (2016) Association between Employment Status and Self-Rated Health: Korean Working Conditions Survey. Annals of Occupational and Environmental Medicine, 28, 43. https://doi.org/10.1186/s40557-016-0126-Z

[34] Bacci, S., Pigini, C., Seracini, M. and Minelli, L. (2017) Employment Condition, Economic Deprivation and Self-Evaluated Health in Europe: Evidence from EU-SILC 2009-2012. International Journal of Environmental Research and Public Health, 14, 143. https://doi.org/10.3390/ijerph14020143

[35] Kim, M.-H., Kim, C.-Y., Park, J.-K. and Kawachi, I. (2008) Is Precarious Employment Damaging to Self-Rated Health? Results of Propensity Score Matching Methods, Using Longitudinal Data in South Korea. Social Science \& Medicine, 67, 1982-1994. https://doi.org/10.1016/j.socscimed.2008.09.051

[36] Tsuragano, S., Inoue, M. and Yano, E. (2012) Precarious Employment and Health: Analysis of the Comprehensive National Survey in Japan. Industrial Health, 50, 223-235. https://doi.org/10.2486/indhealth.MS1260

[37] Virtanen, M., Kivimäki, M., Joensuu, M., Virtanen, P., Elovainio, M. and Vahtera, J. (2005) Temporary Employment and Health: A Review. International Journal of Epidemiology, 34, 610-622. https://doi.org/10.1093/ije/dyi024

[38] Virtanen, P., Janlert, U. and Hammarström, A. (2011) Exposure to Temporary Employment and Job Insecurity: A Longitudinal Study of the Health Effects. Occupational and Environmental Medicine, 68, 570-574. https://doi.org/10.1136/oem.2010.054890

[39] Virtanen, P., Vahtera, J., Kivimäki, M., Pentti, J. and Ferrie, J. (2002) Employment Security and Health. Journal of Epidemiology and Community Health, 56, 569-574. https://doi.org/10.1136/jech.56.8.569

[40] Liukkonen, V., Virtanen, P., Kivimäki, M., Pentti, J. and Vahtera, J. (2004) Social Capital in Working Life and the Health of Employees. Social Science \& Medicine, 59, 2447-2458. https://doi.org/10.1016/j.socscimed.2004.04.013 


\section{Appendix}

Typology of the trajectory change of work-related factors (occupation, employment contract, working-time, wage) between 2003 and 2012.

\section{2}

\begin{tabular}{|c|c|c|c|c|c|}
\hline \\
\hline Occupation & $\begin{array}{l}\text { Level 1: Legislators, } \\
\text { senior official, } \\
\text { managers, and } \\
\text { professionals }\end{array}$ & $\begin{array}{c}\text { Level 2: Technicians and } \\
\text { associate professionals, } \\
\text { armed forces }\end{array}$ & $\begin{array}{l}\text { Level 3: Clerks, } \\
\text { service workers, } \\
\text { shop and market } \\
\text { sales workers }\end{array}$ & $\begin{array}{l}\text { Level 4: Skilled } \\
\text { agricultural } \\
\text { workers, craft, and } \\
\text { skilled workers }\end{array}$ & $\begin{array}{c}\text { Level 5: } \\
\text { Elementary } \\
\text { occupation }\end{array}$ \\
\hline $\begin{array}{l}\text { Level 1: Legislators, senior official, } \\
\text { managers, and professionals }\end{array}$ & $+/+$ & $+1-$ & $+1-$ & $+1-$ & $+1-$ \\
\hline $\begin{array}{l}\text { Level 2: Technicians and associate } \\
\text { professionals, armed forces }\end{array}$ & $-1+$ & $+/+$ & $+1-$ & $+1-$ & $+1-$ \\
\hline $\begin{array}{l}\text { Level 3: Clerks, service workers, } \\
\text { shop and market sales workers }\end{array}$ & $-1+$ & $-1+$ & $-1-$ & $+1-$ & $+1-$ \\
\hline $\begin{array}{l}\text { Level 4: Skilled agricultural } \\
\text { workers, craft, and skilled workers }\end{array}$ & $-1+$ & $-1+$ & $-1+$ & $-1-$ & $+1-$ \\
\hline 2003 Level 5: Elementary occupation & $-1+$ & $-1+$ & $-1+$ & $-1+$ & $-1-$ \\
\hline Employment contract & Permanent contracts & Others & & & \\
\hline Permanent contracts & $+/+$ & $+1-$ & & & \\
\hline Others & $-1+$ & $-1-$ & & & \\
\hline Working-time & Full-time & Part-time & & & \\
\hline Full-time & $+/+$ & $+1-$ & & & \\
\hline Part-time & $-1+$ & $-1-$ & & & \\
\hline Wage quartile & 1st quartile & 2nd quartile & 3 rd or 4 th quartile & & \\
\hline 2nd quartile & $+1-$ & $-1-$ & $-1+$ & & \\
\hline 3 rd or 4 th quartile & $+1-$ & $+1-$ & $+/+$ & & \\
\hline
\end{tabular}

- NB: Level 1 was the top position and level 5 was the bottom position; (+) and (-) were considered as positive or negative position, respectively.

- Change in economic activity between 2003 and 2012.

- Change in economic activity was assessed by one question (answer items: yes or no).

- Change in occupation.

- This was considered positive when the individual held a more qualified occupation in 2012 than he/she had in 2003 ( $-/+$ : level of occupation in $2003<$ level of occupation in 2012). The change was considered negative if the occupation in 2012 required less qualification than the occupation in 2003 (+/-: level of occupation in 2003 > level of occupation in 2012). There was no change if the occupation required the same qualification in 2003 and 2012: a distinction is, however, made between stability in a highly qualified occupation (+/+: level of occupation 1 or 2 in 2003 and 2012$)$ and stability in a low-skilled occupation (-/-: level of occupation 3, 4 or 5 in 2003 and 2012). Sign (-) represents the low-skilled occupations (level of occupation: 3, 4, or 5).

- Development of the professional path.

- This represented the continuity of the career through the number of periods of unemployment or inactivity (none or at least one).

- Wage change.

- This occurred when the individual was not in the same quartile in 2003 as in 2012; it was defined as stable otherwise. The wage changed positively if he/she reached an upper quartile $(-/+)$ and negatively if he/she decreased $(+/-)$. There was negative stability $(-/-)$ if the wage remained the same, but within the lowest quartile, i.e. in the 1 st and 2 nd, and there was positive stability $(+/+)$ if the wage remained the same, but in the highest quartiles $(3 \mathrm{rd}$ and 4 th quartiles) between 2003 and 2012. 